\title{
HUMAN RESOURCE OUTSOURCING: LESSON FROM MULTINATIONAL ENTERPRISES
}

\author{
Hasliza Abdul-Halim ${ }^{1}$; Norbani Che-Ha ${ }^{2}$ \\ ${ }^{1}$ School of Management, Universiti Sains Malaysia \\ 11800 Pulau Pinang, Malaysia \\ ${ }^{2}$ Faculty Business and Accountancy, University Malaya \\ 50603 Kuala Lumpur, Malaysia \\ haslizahalim@usm.my; norbanicheha@um.edu.my
}

\begin{abstract}
This paper examines the consequence of the organization internalization on the practice of human resource (HR) outsourcing among manufacturing organizations. The assumption is that HR outsourcing is perceived as an innovative practice and that multinational enterprise (MNEs) will employ this practice more than local organizations. The data was gathered from survey questionnaires of 232 manufacturing organizations. Of the sample, 113 organizations engaged with HR outsourcing, and 71 are MNEs that partially outsource their HR functions. The findings reveal that HR outsourcing among MNEs is used to a greater extent than local organizations. A significant difference is found in the extent of outsourcing payroll, benefits, training and recruitment between MNEs and in local organizations.
\end{abstract}

Keywords: outsourcing, human resource management, multinational corporations

\begin{abstract}
ABSTRAK
Tulisan ini memeriksa konsekuensi organisasi internasional dalam praktik bagian outsource sumber daya manusia (SDM) dalam organisasi manufaktur. Asumsi awal yaitu bahwa SDM outsource dianggap sebagai praktik inovatif and bahwa perusahaan multinasional akan mempekerjakan praktik ini lebih banyak daripada perusahaan lokal. Sebagai contoh, 113 organisasi mempekerjakan SDM oursource dan 71 di antaranya adalah perusahaan multinasional. Jumlah tersebut mengungkapkan bahwa SDM outsource diantara perusahaan multinasional menunjukan jumlah lebih besar daripada perusahaan lokal. Perbedaan signifikan ditemukan dalam perpanjangan gaji outsource, benefit, training, dan rekrutmen antara perusahaan multinasional dan lokal.
\end{abstract}

Kata kunci: outsource, sumber daya manusia, perusahaan multinasional 


\section{INTRODUCTION}

In the international management and human resource management (HRM) literature, foreign MNEs as opposed to local organizations are different in terms of management and decision-making. This is because in today's world of ever increasing competition and emphasis on the bottom, MNEs necessarily and continuously examine new ways to generate value and improve profitability, including cost reductions where possible. Successful MNEs find ways to utilize their corporate capabilities to add value. MNEs follow different strategies in promoting convergence of organizational forms and practices. Among these strategies, MNEs have embraced outsourcing where appropriate. Indeed Quinn (2000) argued that strategic management of outsourcing is perhaps the most powerful tool in management and outsourcing of innovation is its frontier. Consistent with this trend, MNE engage in HR outsourcing. To a great extent, MNEs are important disseminators of HR practices and innovations in terms of work organization. And, although HR outsourcing is discussed in the management literature, this concept has not been addressed widely under the heading of international management.

Therefore, this paper attempts to investigate the effect of MNEs on the extent of HR outsourcing, drawing upon the findings of an in-depth survey among manufacturing organization in Malaysia. The discussion on this paper will proceed with the concept of HR outsourcing and MNEs, followed by methodology of the study, results and finally the discussion and conclusion of the study.

\section{Literature Review}

\section{HR Outsourcing}

Outsourcing in general can be defined as the purchase from external vendors of a valuecreating activity that either was previously done or could have been done in-house (Gilley \& Rasheed, 2000). Consequently, the outsourcing of HR activities is the practice of turning overall or part of an organization's HR function to external providers (Adler, 2003; Pelham, 2002). HR outsourcing has grown in popularity since the early 1990s in Western Europe and in the US, where up to 90 percent of the organization outsource some HR functions (Cook, 1999; Cooke et al., 2005). However, in other countries such as Greece, the use of HR outsourcing lags well behind this penetration rate (Galanaki \& Papalexandris, 2005). Moreover, empirical study on HR outsourcing in developing countries such as Malaysia (which inter alia is characterised by the presence of many MNE's) is also non existent (Hewitt Association, 2006), revealing an unusual lacuna in the literature.

Many MNEs managers realize that the use of outside providers is more efficient and less costly than hiring full time staff to handle the HR functions in house (Galanaki \& Papalexandris, 2007). In fact, demands for increased productivity, profitability, and growth have encouraged organizations to analyse their internal HR processes, resulting in a move towards strategic outsourcing activities (Cooke, et al., 2005). Moreover, HR outsourcing enables organizations to profit from the rising comparative advantage of specialized service providers who have expertise in the areas concerned (Smith et al., 2006; Cooke et al., 2005). Apart from that, HR outsourcing allows organizations and external vendors to collaborate their consultative and strategic roles in designing and implementing programs which to enhance organizational performance (Greer et al., 1999). In short, the main reasons for outsourcing HR appear to be fairly consistent. Typical reasons include seeking specialist services and expertise, enhancing the quality of the services, cost reduction and enabling HR specialists to take on a more strategic role.

Nonetheless, outsourcing can also fail for several reasons such as high costs and unforeseen need of additional resources (Lawler \& Mohrman, 2003); loss of management control (Quinn \& Hilmer, 1994; Domberger, 1998); declining innovation (Kotabe, 1992); contract ambiguity and technological incompatibilities (Laabs, 1998); potential lower service quality (Elmuti, 2003) and effect 
on employees' morale (Stroh \& Treehuboff, 2003). Similarly, heavy reliance on external service providers may lead to a loss of internal expertise, skills, and strategic competitive advantage (Ulrich, 1996; Adler, 2003).

However, some MNEs may turn to outsourcing as they deem that most vendors have made major investments in HRM knowledge, which they put in the service of their customers. In this sense, outsourcing permits benefiting of knowledge and competencies which do not exist in-house, or, which are used for other activities (Galanaki \& Papalexandris, 2007). Recent research in this domain show a considerable increase in the use of HR outsourcing, particularly in the areas of HRM consultancy and in the design of HRM tools (Cook, 2003; Cook, 2006). This practice has increased mainly due to the existing of competent and experienced HR professionals among the external vendors. Moreover, if the HR functions are adequately standardized, thus HR managers and external vendors are able to communicate effectively and manage in collaborative common projects. Thus, the practice of HR outsourcing could be acknowledged as a demonstration of development of the HRM practice.

\section{Types of HR Functions to be Outsourced}

Evidence now suggests that HR outsourcing has increased considerably over the last decade (Andersen, 1996; Harkins, Brown \& Sullivan, 1995). Qualitative and quantitative reports such as the Cranet Survey and from the Bureau of National Affair provides further evidence of this growth (see below). A recent survey by Smith, et al (2006), indicates that 61 percent of the organisations in Russia outsourced at least one HR function. Out of that percentage, 68 percent of them outsourced recruitment, 61 percent outsourced human resource information system followed by training (56\%) and benefits administration (49\%). Another survey conducted by the Bureau of National Affairs in 2004 (in Lilly et al., 2005) demonstrates that 67 percent of HR departments outsourced one or more HR functions.

The Cranet Survey (in Cooke et al., 2005) provides further evidence to support the growing trends towards HR outsourcing. The survey shows that 97 percent of the organisations use external providers in HR to cover at least one HR function. From various HR functions, training activities are the most common functions to be outsourced (77\%). This is followed by recruitment (59\%), benefits (30\%) and workforce outplacement (29\%).

Organisations outsource a wide range of HR functions. Lever (1997) indicates that 75 percent and 65 percent of the organisations outsource benefits administrations and training respectively. Payroll is also one of the popular HR functions to be outsourced (62\%), followed by recruitment with 50 percent. Other outsourced functions comprise of HR information systems (30\%) and compensation (17\%). None of the respondent outsourced strategic HR functions.

The surveys suggest that many organizations outsource various types of HR functions particularly training and recruitment functions. This indicates that the trend towards HR outsourcing is growing tremendously. Nevertheless, the offer of HR functions in Asia countries including Malaysia has only recently developed (Hewitt Association, 2006). In fact, outsourcing in general is a relatively new phenomenon in Malaysia.

\section{HR Outsourcing and MNEs}

Hyper-competition in globalized market place added with the fact that needs among global customers are becoming common induces multinational enterprises (MNEs) to adopt standardized strategies and practices in fostering employment across border. In this regard, MNEs are considered as the medium of globalization in which they disperse the managerial knowledge and techniques internationally and promoting standardization of management systems (Quintanilla \& Ferner, 2003; Martin \& Beaumont, 1998). However, national differences particularly institutional and culture 
background demand MNEs to adapt their management practices to the local context (Quintanilla \& Ferner, 2003). HR functions specifically, are considered as the most vulnerable to cultural differences and least likely to be standardized across countries (Myloni, Harzing, \& Mirza, 2004). In other words, MNEs are bound to follow local institutional arrangement such as wage determination, hours of work, forms of work contract and redundancy procedures as well as in staffing, employee development, payroll or other HR policies (Ferner, 1997). However, many MNEs do not have ultimate knowledge on the HR functions at the local context, it is reasonable for the organizations to outsource with service providers to handle the functions according to local needs.

Local organizations on the other hand, which operates in a non-restricted institutional environment regarding outsourcing agreements, lags behind in the use of HR outsourcing, it is reasonable to expect that foreign MNEs would engage more in the practice of HR outsourcing than the local organizations. Therefore, the research hypothesis is developed as research hypothesis and foreign MNEs outsource more their HR functions than the local organizations.

\section{METHODOLOGY}

\section{Sample and Procedure}

This study used a mail survey questionnaire to obtain data. The questionnaires were targeted to the head of human resource departments, or the person responsible for HR in Malaysian manufacturing organizations. The mailing list was obtained from the Federation of Malaysian Manufacturers Directory (FMM). The survey yielded 232 useable responses from an eligible sample of 990 organizations. This response rate of $23.4 \%$ is similar to other surveys in Malaysia, which tend to obtain a response of between 15-25 percent (Othman, et al., 2001). The targeted respondents were the senior HR managers. While, as discussed below, the use of a single respondent is not ideal, it has very real benefits in terms of costs, and been the method of choice of leading US researchers such as Becker \& Huselid (2006) who state that the wisest use of scarce research resources should be devoted to increasing overall response rates among well-crafted single respondent surveys.

While the respondents in this study were well positioned to provide HR data, it remains possible that a general response bias is affecting the results. Indeed asking HR managers about their own function involves measuring a partial perception of reality (Valverde et al., 2006). To reduce the effects of possible bias, future research might benefit from designs that collect data from multiple respondents within each participating organization. For instance, it would be valuable to incorporate data from managers other than HR managers (e.g. line managers), as their views may well differ (Edgar et al., 2008). Ideally, if time and research funds permit, research on HRM should also tap into the views of workers, and not rely on managerial views. Research has certainly revealed that workforce views on HRM do differ from those of the management (Geare, et al., 2009).

\section{Measurement Instruments}

The data were collected through a more extensive questionnaire on HR outsourcing. To measure the outsourcing level of HR functions, open ended question relating to the percentage of each HR function outsourced was used. The use of HR outsourcing was established through the following questions: Do you outsource part of this HR function? Please indicate the percentage of this activity being outsourced (ranging from 0 to 100 percent). 
The above two questions were posed for each of the following HR functions namely: payroll, HRIS, benefits, compensations, training, recruitment, appraisal, employee relation and HR strategic functions. The selection of these HR functions was based on the HR functions that are widely recognized, accepted and stated as being outsourced frequently in the human resource management (HRM) literature (Delery \& Doty, 1996; Lever, 1997; Smith et al., 2006).

Furthermore, in order to understand the experiences underlying the HR outsourcing functions of Malaysian organisations, the questions were adapted from the study of Elmuti (2003). These constructs were measured on a six-point semantic differential-likert scale. The measurement scales were modified to suit the background of the respondents particularly in their adoption of the HR outsourcing strategy. Finally, the information of the organisations was obtained from questions on organisational background. Computer software- Statistical Package for the Social Sciences (SPSS) version 14 was used to analyse the practices of HR outsourcing between MNEs and local manufacturing organisations in Malaysia.

\section{DISCUSSION}

\section{Profile of the Respondents}

From the survey, the respondents were asked about their involvement with HR outsourcing. Thus, the profile of the organisations that engage with the outsourcing of HR functions is discussed and all the items recapitulated in Table 1.

Table 1 Profile of the Organisations that Outsourced HR Functions

\begin{tabular}{|c|c|c|}
\hline HR Outsourced Organisations & Number & Percentage \\
\hline \multicolumn{3}{|l|}{ 1. HR outsourcing decision } \\
\hline - $\quad$ Yes & 113 & 48.7 \\
\hline - $\quad$ No & 119 & 51.3 \\
\hline \multicolumn{3}{|l|}{ 2. Type of industry } \\
\hline - $\quad$ Food and beverages & 8 & 7.1 \\
\hline - $\quad$ Textiles & 10 & 8.8 \\
\hline - Wood products & 6 & 5.3 \\
\hline - $\quad$ Chemical products & 12 & 10.6 \\
\hline - $\quad$ Rubber and plastic products & 11 & 9.7 \\
\hline - $\quad$ Metal products & 9 & 8.0 \\
\hline - Machinery and equipment & 17 & 15 \\
\hline - Electronics & 16 & 14.2 \\
\hline - $\quad$ Radio, TV and communication & 16 & 14.2 \\
\hline - $\quad$ Motor vehicles, trailers and semi-trailers & 8 & 7.1 \\
\hline \multicolumn{3}{|l|}{ 3. Years in operation } \\
\hline - 20 years above & 41 & 36.3 \\
\hline - $11-20$ years & 40 & 35.4 \\
\hline - 10 years and below & 32 & 28.3 \\
\hline \multicolumn{3}{|l|}{ 4. Total employees } \\
\hline - 150 to 300 employees & 30 & 26.5 \\
\hline - $\quad 301$ to 1000 employees & 46 & 40.7 \\
\hline - $\quad$ Above 1000 employees & 37 & 32.7 \\
\hline \multicolumn{3}{|l|}{ 5. Years of working experience } \\
\hline - $\quad$ Below 5 years & 69 & 61.1 \\
\hline - 5 to 10 years & 34 & 30.1 \\
\hline - $\quad$ Above 10 years & 10 & 8.8 \\
\hline
\end{tabular}


From 232 respondents, 48.7 percent (113) of the organisations engaged in outsourcing their HR functions. Table 1 shows the profile of the 113 organisations that outsourced HR functions. The majority of respondents (15\%) are from the machinery and equipment industry. Almost 41 percent of the organisations employ 301 to 1000 employees, and 36.3 percent of these organisations have been in business for at least 20 years. Interestingly, about 61 percent of respondents have less than five years of experience in HR areas.

\section{Type of Human Resource Functions Outsourced between MNEs and Local Organizations}

Of the 113 responses, 71 (62.8\%) related to MNEs and 42 (37.2\%) were local organizations. The results are presented in Table 2. Percentages for each answer option were computed as 1) fraction of the whole sample of outsourced organizations and 2) a fraction in each category (type of HR functions outsourced) by ownership.

Table 2 HR Outsourcing Survey Results

\begin{tabular}{lcc}
\hline Organizations (N=113) & MNEs & $\begin{array}{c}\text { Local (Malaysian) } \\
\text { Organizations }\end{array}$ \\
\hline 1. Does your organization outsource? Yes & $71(62.8 \%)$ & $42(37.2 \%)$ \\
2. What HR functions does your organization outsource? & & \\
Payroll & $24(33.8 \%)$ & $6(14.3 \%)$ \\
Benefits & $13(18.3 \%)$ & $2(4.8 \%)$ \\
HRIS & $6(8.5 \%)$ & $4(9.5 \%)$ \\
Training & $49(69 \%)$ & $25(59.5 \%)$ \\
Recruitment & $56(78.9 \%)$ & $38(90.5 \%)$ \\
\hline
\end{tabular}

From Table 2, most of the organizations that engaged with HR outsourcing were MNEs (62.8\%). Only 37.2 percent of local organizations partially outsource some of their HR functions. This finding is consistent with the study conducted by Galanaki and Papalexandris (2007) in which local (Greek) organizations outsource less HR functions compared to MNEs. In a similar manner, Smith et al. (2006) also indicate that more than half (57\%) of organizations that outsource HR functions are MNEs. Table 2 also show that recruitment is the most frequently outsourced HR function for MNEs (78.9\%) and local organizations (90.5\%), with training as most likely future outsourcing priority. Routine and administrative HR functions (e.g. HRIS, benefits) for both organizations are among the least functions to be outsourced. This contradicts the popular knowledge that administrative is among the HR functions to be outsourced (Greer et al., 1999). Result for HRIS, however, are in agreement with Lever (1997) that specify only few organizations outsource the function.

\section{The Difference in the use of HR Functions Outsourced by MNEs and Local Organizations}

T-Tests were employed to measure the use of HR outsourcing by each group (MNEs and local organizations). Table 3 shows the results of the T-Tests by each group of the organizations.

Table 3 Results of T-Tests on HR outsourcing

between MNEs and local organizations

\begin{tabular}{cccccc}
\hline Variable & Organizations & N & Mean & F & Sig. \\
\hline HR Outsourcing & MNEs & 71 & 17.34 & 81.044 & $0.000^{*}$ \\
& Local & 42 & 1.95 & & \\
\hline
\end{tabular}

* Significant at 0.01 level 
Result shows that a significant difference was found in the use of HR outsourcing by each group namely MNEs and local manufacturing organizations ( $\mathrm{F}=81.04, \mathrm{p}=0.000)$. MNEs were found to have higher mean scores. This indicates that local organizations outsource less HR functions than MNEs do, thus justify that ownership of the organization (MNEs or local) is a significant indicator in decision making to outsource HR functions. Therefore, the hypothesis formulated is supported. This result is consistent with Galanaki \& Papalexandris (2007) in which multinational organizations tend to engage more with HR outsourcing than the local organizations.

\section{The Difference of Use of HR Outsourcing in MNEs and Local Organizations, by HR Functions}

T-tests were also conducted to test whether the extent of outsourcing of HR functions is different between the two groups. Results are presented in Table 4. The percentage of the total HR function that is outsourced was found to be significantly different in MNEs from local organizations in the case of payroll $(\mathrm{F}=72.77, \mathrm{p}=0.000)$, benefits $(\mathrm{F}=20.82, \mathrm{p}=0.000)$, training $(\mathrm{F}=124.94, \mathrm{p}=0.000)$ and recruitment $(\mathrm{F}=5.817, \mathrm{p}=0.018)$. This suggests that MNEs were found to outsource a significantly larger part of their payroll, benefits, training and recruitment functions than the local organizations do. However, the use of outsourcing HRIS was found not to be significant between MNEs and local organizations.

Table 4 Results of T-Tests for the difference in use of individual HR functions between MNEs and local organizations

\begin{tabular}{llccccc}
\hline HR Functions & Organizations & N & Mean & F & Sig. \\
\cline { 2 - 7 } & Payroll & MNEs & 71 & 15.77 & 72.77 & $0.000^{*}$ \\
& Local & 42 & 1.95 & & \\
& Benefits & MNEs & 71 & 5.00 & 20.82 & $0.000^{*}$ \\
& Local & 42 & 1.40 & & \\
\multirow{2}{*}{ Training } & MNEs & 71 & 37.82 & 124.94 & $0.000^{*}$ \\
& Local & 42 & 1.10 & & \\
& Recruitment & MNEs & 71 & 35.56 & 5.817 & $0.018^{*}$ \\
& Local & 42 & 33.51 & & \\
& HRIS & MNEs & 71 & 4.15 & 1.265 & 0.263 \\
& Local & 42 & 2.86 & & \\
\hline
\end{tabular}

* Significant at 0.01 level

\section{CONCLUSION}

The above findings show that MNEs are significantly different in the use of HR outsourcing as opposed to local organizations. In this instance, more MNEs appear to be outsourcing their HR functions more than local organizations. This finding is supported by Galanaki \& Papalexandris (2005) that majority of MNEs outsource their HR functions. This is because MNEs are more demanding, knowledgeable of their HRM needs and therefore, require more advanced and sophisticated HR services. The findings of this study are important in identifying the trend of HR outsourcing among MNEs and local organizations. The results also show that recruitment and training are among the most popular HR functions to be outsourced by both MNEs and local organizations. This scenario is expected to be driven by the existence of reliable vendors specializing in designing and delivering the training programs as well as their experts in head hunting. Another reason is due to the nature of these functions (recruitment and training) that changes too quickly for internal department to keep up and maintain, therefore outsourcing to specialized vendors is an alternative. 
Moreover, both organizations are found to outsource small parts of payroll, benefits and HRIS functions. The reason for performing most of these functions in house is that, in the Asia Pacific the decision to outsource tends to be made locally. Therefore, most organizations refuse to outsource these functions because of the increasing concern over confidentiality and privacy issues (Stroh \& Treehuboff, 2003; Hewitt Association, 2006). Moreover, the growing complexity of compliance requirements in areas of benefits, HRIS and compensations made them unattractive for the external vendors. This might also imply that it will take a longer time for organizations in Asia to build trust and confidence in a vendor, thereby extending the period from the initial contract to an ongoing relationship (Hewitt Association, 2006). It should be pointed out that, the findings also indicate that there is a significant difference in terms of outsourcing payroll, benefits, training and recruitment between MNEs and local organizations. This explains that MNEs tend to engage more with external vendors in outsourcing these functions as compared to local organizations.

A major limitation of this study is due to its small sample size. Moreover, this study only concentrates on manufacturing organizations as the key respondents; hence generalization on the findings to service organizations may be a challenge. Thus, future studies should gather more samples and also include service organizations, in that, the role of HR outsourcing could be better understood from two different industries. Moreover, plan for future research include deeper understanding on the factors that trigger the MNEs and local organization to outsource their HR functions. In fact, the relationship between HR outsourcing and organizational performance would be interesting to scrutinize. In summary, this paper allows the HR managers to rethink the delivery of HR functions. There are many alternative delivery mechanisms that remove the delivery of HR practices from HR department (Lepak et al. 2005). HR outsourcing is not the only option available. There is also some evidence that a large number of HR functions are shifted to line management (Larsen and Brewster 2003). For HR managers it is important to scrutinize these alternatives delivery mechanism, to weigh their pros and cons and to select the mechanism that match the business strategy of the organizations.

\section{REFERENCES}

Adler, P. S. (2003). Making the HRM Outsourcing Decision. MIT Sloan Management Review, 45, 5360.

Andersen, A. (1996). Outsourcing human resource functions. Supervision, 57, 3.

Becker, B. E., \& Huselid, M. A. (2006). Strategic Human Resources Management: Where Do We Go from Here? Journal of Management, 32(b), 898-925.

Cook, M. F. (1999). Outsourcing human resources functions: Strategies for providing enhanced HR services at lower cost. New York: AMACOM.

Cooke, F. L., Shen, J., \& McBribe, A. (2005). Outsourcing HR as a Competitive Strategy? A Literature Review and an Assessment of Implications. Human Resource Management, 44(4), 413-432.

Delery, J. E., \& Doty, D. H. (1996). Modes of Theorizing in Strategic Human Resource Management: Test of Universalistic, Contingency and Configural Performance Prediction. Academy of Management Journal, 39(4), 802-35.

Domberger, S. (1998), The Contracting Organization - A strategic Guide to Outsourcing, Oxford: Oxford University Press. 
Edgar, F. J., Geare, A. J., \& McAndrew, I. (2008). Dispelling a Myth? Union Affiliation and Its Impact on Affiludinal Outcomes. International Journal of Comparitive Labour Law and Industrial Relations. 24(4), 549-572.

Elmuti, D. (2003). The Perceived Impact of Outsourcing on Organizational Performance. MidAmerican Journal of Business. 18(2), 33-41.

Ferner, A. (1997). Country of Origin Effects and HRM in Multinational Companies. Human Resource Management Journal, 7(1), 19-36.

Galanaki, E., \& Papalexandris, N. (2005). Outsourcing human resource management in Greece. International Journal of Manpower, 26(4), 382-96.

Geare, A. J., Edgar, F. J., \& McAndrew, I. (2009). Workplace Values and Beliefs: an Empirical Study of Ideology, High Commitment Management and Unionisation. International Journal of Human Resource Management, 20(5): 1145-1170.

Gilley, M., \& Rasheed, A. (2000). Making More by Doing Less: an Analysis of Outsourcing and Its Effect on Firm Performance. Journal of Management, 26(4),763-790.

Greer, C. R., Youngblood, S. A., \& Gray, D. A. (1999). Human Resource Management Outsourcing: The Make or Buy Decision'. Academy of Management Executive. 13, 85-96.

Harkins, P. J., Brown, S. M. \& Sullivan, R. (1995). Shining New Light on a Growing Trend. HR Magazine, pp.75-79.

Hewitt Association. (2006). Available from: http://www.hewittassociates.com/Intl/NA/enUS/Default.aspx [Accessed 10 February 2008].

Kotabe, M. (1992). Global Sourcing Strategy: R\&D, Manufacturing, and Marketing Interfaces. Newyork: Quorum.

Laabs, J. (1998). The Dark Side of Outsourcing. Workforce, 77, 17-18.

Lawler, E. E., Mohrman, S. A., (2003). HRM as a Strategic Partner: What Does It Take to Make It Happen? Human Resource Planning. 26,15-29.

Lepak, D. P., Bartol, K. M., \& Erhardt, N. L. (2005). A Contingency Framework for the Delivery of HR Practices. Human Resource Management Review, 15,139-159.

Lever, S. (1997). An Analysis of Managerial Motivations behind Outsourcing Practices in Human Resources. Human Resource Planning, 20(2), 37-47.

Lilly, J. D., Gray, D. A., \& Virick, M. (2005). Outsourcing the Human Resource Function: Environmental and Organizational Characteristics That Affect HR Performance. Journal of Business Strategies, 22(1), 55-72.

Martin, G., \& Beaumont, P. (1998). Diffusion 'Best Practice' in Multinational Firms: Prospects, Practice and Contestation. The International Journal of Human Resource Management, 9(4), 671-95.

Myloni, G., Harzing, W-W., \& Mirza, H. (2004). Human Resource Management in Greece. Have the Colours of Culture Faded away? International Journal of Cross Cultural Management, 4(1), 59-76. 
Othman, R., Arshad R., Hashim, N., \& Md Isa, R. (2005). Psychological Contract Violation and Organizational Citizenship Behavior. Gadjah Mada International Journal of Business 7: 325 349.

Pelham, D. (2002). Is it time to outsource HR? Training 39 (4):50 Minneapolis.

Quinn, J. B., \& Hilmer, F.G. (1994). Strategic Outsourcing. Sloan Management Review, 35(4), 43-45.

Quinn, J.B. (2000). Outsourcing innovation: The new engine of growth. Sloan Management Review 41(4), 13-29.

Quintanilla, J., \& Ferner, A. (2003). Multinationals and Human Resource Management: Between Global Convergence and National Identity. The International Journal of Human Resource Management, 14(3), 363-68.

Smith, P. C., Vozikis, G. S., \& Varaksina, L. (2006). Outsourcing Human Resource Management: A Comparison of Russian and U.S. Practices. Journal of Labor Research, 27(3), 305-21.

Stroh, L. K., \& Treehuboff, D. (2003). Outsourcing HR Functions: When-and When Not-to Go Outside. Journal of Leadership and Organizational Studies, 10, 19-28.

Ulrich, D. (1996). Human Resource Champions: The Next Agenda for Adding Value and Delivering Results. Boston: Harvard University Press.

Valverde, M., Ryan, G., \& Soler, C. (2006). Distributing HRM responsibilities: a classification of organizations, Personnel Review, Vol. 35 No.6, pp.618-36. 